\title{
PENGEMBANGAN MODEL PEMBELAJARAN OSCAR UNTUK MELATIH PENALARAN SISWA SEKOLAH DASAR DALAM MENYELESAIKAN MASALAH MATEMATIKA
}

\author{
Iis Holisin 1)", Chusnal 'Ainy ${ }^{2)}$, dan Wiwi Wikanta ${ }^{3)}$ \\ 1,2) Jurusan Pendidikan Matematika, Fakultas Keguruan dan Ilmu Pendidikan \\ 3) Jurusan Pendidikan Biologi, Fakultas Keguruan dan Ilmu Pendidikan \\ Universitas Muhammadiyah Surabaya \\ J1. Sutorejo 59 Surabaya, Kode Pos 60113 \\ *iisholisin.pendmat@fkip.um-surabaya.ac.id
}

\begin{abstract}
Abstrak
Tujuan penelitian ini adalah untuk mengembangkan model pembelajaran OSCAR yang valid, praktis, dan efektif untuk melatih penalaran siswa dalam menyelesaikan masalah matematika. Metode yang digunakan adalah penelitian pengembangan dengan menggunakan model dari Plomp yang terdiri dari 5 fase, yaitu (1) investigasi awal, (2) desain, (3)realisasi,(4) tes, evaluasi, dan revisi, serta (5) implementasi. Subyek penelitiannya adalah guru matematika dan siswa-siswi kelas V SD tahun ajaran 2017/2018. Penelitian dilaksanakan pada bulan September 2017 sampai April 2018 di SD Muhammadiyah 5, SD Islam Maryam, SD Islam Saroja, dan SD Negeri Sidotopo Wetan I. Semua sekolah berlokasi di Kota Surabaya. Instrumen yang digunakan adalah angket, lembar observasi dan masalah matematika. Selain mengembangkan model pembelajaran, perangkat pembelajaran yang dikembangkan adalah RPP, LKS, dan bahan ajar. Hasil penelitian menunjukkan bahwa model pembelajaran OSCAR yang dikembangkan telah memenuhi kriteria valid, praktis, dan efektif. Hal ini ditunjukkan oleh perolehan nilai rata-rata validitas sebesar 3,32 yang menunjukkan kriteria valid. Aspek kepraktisan ditunjukkan oleh pernyataan para validator bahwa model pembelajaran OSCAR dapat dilaksanakan di lapangan. Aspek efektif ditunjukkan oleh nilai rata-rata keterlaksanaan proses pembelajaran sebesar 3,56 termasuk kategori sangat baik; respon siswa terhadap penerapan model pembelajaran OSCAR 68\% menyatakan senang, 78\% menganggap baru, seluruh siswa senang terhadap cara guru mengajar; rata-rata kemampuan penalaran siswa mengalami peningkatan, hal ini ditunjukkan oleh besarnya rata-rata nilai $\mathrm{N}$-gain antara 0,350,43 dan termasuk kategori sedang.
\end{abstract}

Kata Kunci: model pembelajaran OSCAR, penalaran, masalah matematika. 


\section{PENDAHULUAN}

Penalaran merupakan proses berpikir logis seseorang dalam mengambil suatu keputusan atau membuat suatu pernyataan (Holisin, 2017). Kemampuan bernalar dapat dilatihkan melalui belajar matematika, karena dalam belajar matematika setiap siswa dilatih untuk belajar berpikir logis. Oleh karena itu penalaran dan materi matematika tidak dapat dipisahkan. Walaupun penalaran identik dengan matematika, namun kemampuan bernalar dibutuhkan oleh setiap siswa tidak hanya saat belajar matematika saja. Kemampuan bernalar dibutuhkan juga pada saat memecahkan masalah atau saat menentukan keputusan (Shadiq, 2004). Kedua pendapat tersebut menunjukkan bahwa kemampuan bernalar perlu dimiliki oleh setiap orang.

Kemampuan bernalar perlu dilatihkan sejak dini. Latihan tersebut dapat dilakukan oleh guru melalui proses pembelajaran dengan berbagai cara. Misalnya melalui belajar kelompok, diskusi, atau memberikan masalah-masalah yang berkaitan dengan kehidupan sehari-hari. Kemampuan bernalar akan terjadi apabila siswa selama proses pembelajaran terlibat secara aktif, baik aktivitas fisik maupun mental. Contoh aktivitas fisik diantaranya siswa menggambar, melipat kertas, membuat alat peraga, dan lain sebagainya. Sedangkan aktivitas mental contohnya berdiskusi, mengamati yang dilanjutkan dengan membuat simpulan, dan sebagainya.

Kegiatan bernalar berhubungan juga dengan pemecahan masalah. Ada lima pola perilaku pemecahan masalah oleh siswa, yaitu (1) Direct Translation Approach (DTA-proficient); (2) DTA-not proficient; (3) DTA-limited context; (4) Meaning Based Approach (MBA-full context); dan (5) MBAJustification (Pape, 2004). Kelima pola perilaku tersebut dikelompokkan menjadi dua kelompok besar, yaitu perilaku DTA dan MBA. Perilaku DTA cenderung menerjemahkan langsung kata-kata yang ada dalam masalah, sedangkan perilaku $M B A$ cenderung menyimpulkan arti dari masalah secara keseluruhan. Hasil penelitian Holisin (2017) menunjukkan bahwa penalaran siswa perempuan dalam menyelesaikan masalah pecahan cenderung termasuk DTA, yaitu cenderung memperhatikan kata-kata kunci yang ada dalam masalah. Sedangkan siswa laki-laki cenderung termasuk $M B A$, yaitu memperhatikan makna masalaah secara keseluruhan.

Tidak sedikit siswa yang pandai masih mengalami kesulitan apabila diberi masalah dalam bentuk soal cerita. Salah satu penyebabnya adalah guru masih fokus kepada pencapaian kemampuan siswa dalam berhitung dan menggunakan rumus matematika (Lidinillah, 2008). Masih banyak guru beranggapan bahwa kemampuan pemecahan masalah merupakan kemampuan ekstra atau tambahan. Biasanya hanya siswa yang memiliki kemampuan tinggi yang diberi latihan soal berupa masalah yang menantang. Padahal pemecahan masalah merupakan salah satu kompetensi yang menjadi fokus pembelajaran matematika (Usman, 2014). Salah satu alasan mengapa matematika perlu diajarkan adalah "memberikan kepuasan terhadap usaha memecahkan masalah yang menantang" (Cockfort dalam Rosiyanti dan Widyasari, 2017). Oleh karena itu pembelajaran yang melibatkan pemecahan masalah perlu dibiasakan, walaupun masih di Sekolah Dasar. Aktivitas pemecahan masalah berkaitan dengan kemampuan bernalar. Siswa yang kemampuan bernalarnya baik, cenderung tidak mengalami kesulitan saat menyelesaikan masalah. 
Berdasarkan uraian di atas perlu dirancang model pembelajaran yang dapat melatih penalaran siswa dalam menyelesaikan masalah. Peneliti mencoba mengembangkan model pembelajaran yang fase-fase nya terdiri dari Orientation, Selfobservation, Construction, Association, dan Reflection (OSCAR). Selain itu proses pengembangan model pembelajaran OSCAR ini memperhatikan aspek-aspek lainnya. Permasalahan pokok dalam penelitian ini adalah bagaimana proses dan hasil pengembangan model pembelajaran OSCAR untuk melatih penalaran siswa SD dalam menyelesaikan masalah matematika?

\section{METODE PENELITIAN}

Penelitian ini termasuk jenis penelitian pengembangan. Subjek penelitian adalah guru matematika dan siswa-siswi kelas V tahun ajaran 2017/2018. Penelitian dilaksanakan di SD Muhammadiyah 5, SD Islam Maryam, SD Islam Saroja, dan SD Negeri I Sidotopo Wetan I. Semua sekolah berlokasi di Kota Surabaya. Objek penelitiannya adalah model pembelajaran OSCAR yang dikembangkan dengan model Plomp. Prosedur pengembangan mengikuti desain dari Plomp (1997), yaitu (1) fase investigasi awal, (2) fase desain, (3) fase realisasi, (4) fase tes, evaluasi, dan revisi, serta (5) fase implementasi.

Kegiatan pada fase awal, peneliti mengkaji penalaran, teori tentang model pembelajaran, teori belajar, menganalisis kondisi siswa, kurikulum, materi, serta menganalisis kondisi lingkungan. Hasil kajian tersebut dijadikan pertimbangan untuk merancang model pembelajaran OSCAR.

Fase desain, peneliti merancang model pembelajaran OSCAR dengan memperhatikan beberapa aspek, yaitu (1) landasan teori, (2) sintaks pembelajaran, yaitu suatu urutan pembelajaran, (3) sistem sosial, yaitu peran siswa dan guru serta aturan yang diperlukan selama pembelajaran, (4) prinsip reaksi, yaitu gambaran yang diberikan kepada guru tentang bagaimana cara memandang dan merespon apa yang dilakukan siswa, (5) sistem pendukung, yaitu kondisi yang diperlukan untuk pelaksanaan suatu model. Misalnya setting kelas, perangkat pembelajaran, dan (6) dampak dari pembelajaran, yaitu hasil belajar yang dicapai langsung, serta dampak pengiring, yaitu hasil belajar yang lain yang dihasilkan oleh suatu proses pembelajaran.

Fase realisasi, peneliti menyusun model pembelajaran sesuai dengan rancangan pada fase desain. Fase realisasi ini dihasilkan prototipe 1 .

Fase tes, evaluasi, dan revisi. Fase ini difokuskan pada dua hal, yaitu (1) memvalidasi, dan (2) melakukan uji coba lapangan prototipe 2 tentang model pembelajaran serta perangkatnya secara teoritis dan uji coba terbatas. Uji coba dilaksanakan dengan menggunakan desain one group pretest-posttest design. Adapun desainnya sebagai berikut:
$\begin{array}{lll}\mathrm{O}_{1} & \mathrm{X} & \mathrm{O}_{2}\end{array}$

$\mathrm{O}_{1}=$ pre-test;

$\mathrm{X}=$ pembelajaran dengan model OSCAR $\mathrm{O}_{2}=$ post test

Fase implementasi, peneliti mengimplementasikan model pembelajaran OSCAR pada skala yang lebih luas. Peneliti menerapkan model pembelajaran OSCAR dalam pembelajaran matematika di beberapa sekolah yang setara dengan kelas uji coba.

Teknik pengumpulan data dilakukan dengan teknik validasi, angket, observasi, serta teknik tes. Instrumen yang digunakan 
terdiri dari lembar validasi, angket, lembar observasi, dan seperangkat tes uraian.

Kegiatan analisis data dalam penelitian ini adalah sebagai berikut, Menganalisis Kelayakan Model, (1) melakukan rekapitulasi terhadap semua pernyataan validator ke dalam tabel yang meliputi aspek (A), kriteria (K), dan hasil penilaian validator $(\mathrm{V})$. Mencari rata-rata hasil validasi dari semua validator untuk setiap kriteria. (2) Mencari validitas tiap aspek (A). (3) Mencari rata-rata validitas (RTV). (4) Menentukan kategori kevalidan (secara teoritis) dengan mencocokkan rerata total dengan kategori berikut

$$
\begin{aligned}
& 3 \leq \mathrm{RTV} \text { model OSCAR } \leq 4: \text { valid } \\
& 2 \leq \mathrm{RTV} \text { model } \mathrm{OSCAR}<3: \text { cukup valid } \\
& 1 \leq \mathrm{RTV} \text { model } \mathrm{OSCAR}<2: \text { tidak valid }
\end{aligned}
$$

Analisis kepraktisan model. Model pembelajaran OSCAR dikatakan praktis apabila para validator menyatakan bahwa model pembelajaran OSCAR dapat digunakan dengan revisi kecil atau tanpa revisi.

Analisis keefektifan model. Model pembelajaran dikatakan efektif bila ada peningkatan kemampuan penalaran siswa setelah diterapkannya model pembelajaran OSCAR, keterlaksanaan proses pembelajaran (KPP) termasuk kategori baik, dan respon siswa terhadap model pembelajaran OSCAR termasuk kriteria kuat.

Penarikan simpulan ada tidaknya peningkatan didasarkan pada besarnya nilai $N$-gain dari Hake (Wiyono, 2013). Adapun rumus yang digunakan adalah

dengan:

$$
N-\text { gain }=\frac{s_{\text {post }}-S_{\text {pre }}}{S_{\text {maks }}-S_{\text {pre }}}
$$

$S_{\text {post }}=$ skor tes akhir,

$S_{\text {maks }}=$ skor maksimum, dan

$S_{\text {pre }}=$ skor tes awal
Selanjutnya nilai $N$-gain dikelompokkan sebagai berikut:

Kelompok tinggi $\quad N$-gain $>7,00$

Kelompok sedang $\quad 0,3<N$-gain $<0,7$

Kelompok rendah $\quad N$-gain $<0,3$

Penarikan kesimpulan KPP didasarkan pada kriteria berikut:

$$
\begin{array}{ll}
3<K P P \leq 4 & \text { Sangat Baik } \\
2<K P P \leq 3 & \text { Baik } \\
1<K P P \leq 2 & \text { Kurang Baik }
\end{array}
$$

Penarikan kesimpulan respon siswa terhadap model pembelajaran OSCAR didasarkan pada kriteria interpretasi skor angket sebagai berikut:

$\begin{array}{lll}\text { Angka } 0 \%-20 \% & \text { sangat lemah } \\ \text { Angka } 21 \%-40 \% & \text { lemah } \\ \text { Angka } 41 \%-60 \% & \text { cukup } \\ \text { Angka } 61 \%-80 \% & \text { kuat } \\ \text { Angka } 81 \%-100 \% & \text { sangat kuat }\end{array}$

\section{HASIL DAN PEMBAHASAN}

Pengembangan model pembelajaran OSCAR ini menggunakan fase-fase model pengembangan dari Plomp, yaitu fase (1) investigasi awal, (2) desain, (3) realisasi, (4) tes, evaluasi, dan revisi, dan (5) implementasi.

\section{Fase Investigasi Awal}

Hasil dari investigasi awal diperoleh bahwa teori yang mendukung adalah teori konstruktivis, teori belajar penemuan, penalaran, teori model pembelajaran, serta strategi pemecahan masalah. Kurikulum yang digunakan adalah kurikulum 2013 yang sudah direvisi. Siswa-siswi yang menjadi subjek penelitian memiliki kemampuan akademik, kemampuan bernalar, serta kemampuan komunikasi yang beragam. Siswa terbiasa dengan soal-soal rutin, bukan soal pemecahan masalah. 


\section{Fase Desain}

Hasil fase desain adalah merancang sintaks pembelajaran yang terdiri dari lima fase, yaitu orientation, self-observation, construction, association, dan reflection (OSCAR). Selain itu dirancang pula perangkat pembelajaran terdiri dari Lembar Kerja Siswa (LKS), buku ajar, Rencana Pelaksanaan Pembelajaran (RPP), dan instrumen penelitian.

\section{Fase Realisasi}

Hasil fase realisasi adalah model pembelajaran OSCAR prototipe 1 serta perangkat pembelajaran sebagai pendukung.

\section{Fase Tes, Evaluasi, dan Revisi}

Hasil pada fase tes, evaluasi, dan revisi ada dua, yaitu hasil validasi dan hasil uji coba. Hasil analisis terhadap validasi yang dilakukan validator digunakan untuk merevisi model pembelajaran yang sedang dikembangkan. Kegiatan validasi dilakukan oleh 5 orang ahli, terdiri dari 3 dosen ahli pembelajaran matematika, 1 dosen ahli pendidikan sains, dan seorang guru SD sebagai praktisi. Adapun rekapitulasi hasil validasi terhadap model pembelajaran OSCAR disajikan pada Tabel 1.

Tabel 1. Hasil Validasi Ahli terhadap Model Pembelajaran OSCAR

\begin{tabular}{clcc}
\hline No & Aspek Penilaian & $\begin{array}{c}\text { Rata- } \\
\text { rata }\end{array}$ & $\begin{array}{c}\text { Krite- } \\
\text { ria }\end{array}$ \\
\hline 1 & Landasan Teoritis & 3,50 & Valid \\
\hline 2 & $\begin{array}{l}\text { Sintaks } \\
\text { Pembelajaran }\end{array}$ & 3,30 & Valid \\
\hline 3 & Sistem Sosial & 3,50 & Valid \\
\hline 4 & Sistem Pendukung & 3,17 & Valid \\
\hline 5 & Prinsip Reaksi & 3,21 & Valid \\
\hline 6 & $\begin{array}{l}\text { Dampak } \\
\text { Pembelajaran }\end{array}$ & 3,22 & Valid \\
\hline & & &
\end{tabular}

\begin{tabular}{ccc}
\hline No Aspek Penilaian & $\begin{array}{c}\text { Rata- } \\
\text { rata }\end{array}$ & $\begin{array}{c}\text { Krite- } \\
\text { ria }\end{array}$ \\
\hline $\begin{array}{c}\text { Rata-rata Total Validitas } \\
(\text { RTV })\end{array}$ & 3,32 & Valid \\
\hline
\end{tabular}

Subanji (2013) mengatakan "ada lima masalah yang harus diperhatikan dalam mengembangkan model, yaitu sintaks, sistem sosial, prinsip reaksi, sistem pendukung, dampak instruksional, dan dampak pengiring”. Sedangkan menurut Aqib (2013) "setiap model pembelajaran memiliki empat ciri khusus, yaitu (1) Landasan teoritik, (2) Hasil belajar siswa, (3) Sintaks, serta (4) Lingkungan belajar dan sistem pengelolaan. Ciri-ciri model pembelajaran tersebut sudah terpenuhi oleh data yang ada pada Tabel 1 .

Data pada Tabel 1 menunjukkan bahwa model pembelajaran OSCAR yang dikembangkan valid. Selain itu para validator menyatakan bahwa model pembelajaran OSCAR yang dikembangkan dapat dilaksanakan di lapangan dengan sedikit revisi. Pernyataan dari ahli dan praktisi tersebut merupakan data kepraktisan, yaitu model pembelajaran OSCAR dapat dilaksanakan di kelas.

Beberapa saran yang diberikan oleh validator adalah (1) perilaku dalam membimbing dan mengidentifikasi perlu lebih diperjelas secara tertulis, karena yang diajar anak SD yang belum memahami bagaimana cara mengidentifikasi; (2) Langkah construction dan association belum terlihat kapan siswa dibentuk kelompok.

Setelah memperhatikan saran dan masukan dari validator, sintaks model pembelajaran OSCAR direvisi diperoleh draft II. Sintaks model OSCAR yang sudah direvisi disajikan pada Tabel 2. 
Tabel 2. Sintax Model Pembelajaran OSCAR

\begin{tabular}{|c|c|c|}
\hline Fase & Perilaku Guru & Perilaku Siswa \\
\hline $\begin{array}{l}\text { Fase 1: } \\
\text { Orientation }\end{array}$ & 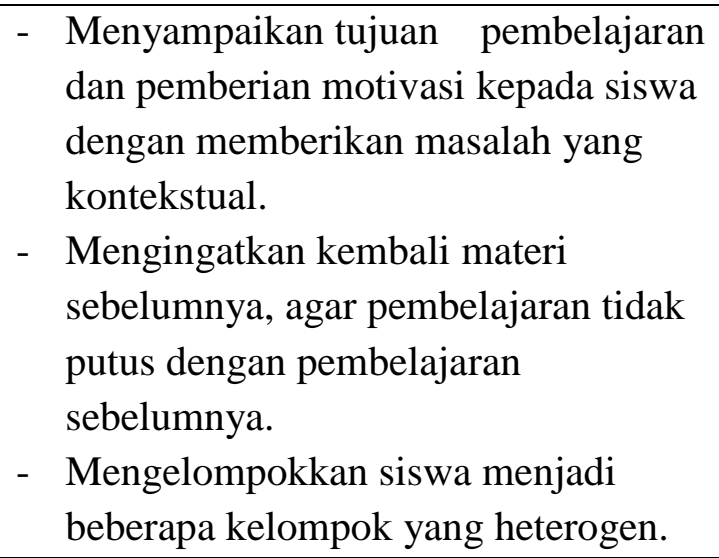 & $\begin{array}{l}\text { Mendengarkan penjelasan guru, } \\
\text { menjawab atau mengerjakan soal } \\
\text { yang diberikan oleh guru }\end{array}$ \\
\hline $\begin{array}{l}\text { Fase } 2: \text { Self- } \\
\text { Observation }\end{array}$ & $\begin{array}{l}\text { - Membimbing siswa mengumpulkan } \\
\text { informasi, mengkaji dan mencermati } \\
\text { masalah yang ada pada LKS } \\
\text { - Memotivasi siswa untuk mengiden- } \\
\text { tifikasi masalah. }\end{array}$ & $\begin{array}{l}\text { - Mendengarkan penjelasan guru } \\
\text { dan mencatat masalah yang } \\
\text { diberikan. } \\
\text { - Mengidentifikasi yang diketahui } \\
\text { dan yang ditanyakan secara } \\
\text { individu. } \\
\end{array}$ \\
\hline $\begin{array}{l}\text { Fase 3: } \\
\text { Construction }\end{array}$ & $\begin{array}{l}\text { - Membimbing siswa menganalisis } \\
\text { informasi dan mengkonstruksi } \\
\text { langkah-langkah penyelesaian } \\
\text { masalah. } \\
\text { - Membimbing siswa menyelesaikan } \\
\text { masalah secara individu. }\end{array}$ & $\begin{array}{l}\text { - Mengkonstruksi langkah-langkah } \\
\text { untuk menyelesaikan masalah. } \\
\text { - } \text { Menyelesaikan masalah. } \\
\text { - } \quad \text { Diharapkan setiap siswa memiliki } \\
\text { hasil konstruksi yang berbeda. }\end{array}$ \\
\hline $\begin{array}{l}\text { Fase 4: } \\
\text { Association }\end{array}$ & $\begin{array}{l}\text { - Meminta siswa bergabung dengan } \\
\text { kelompok untuk berdiskusi } \\
\text { menyelesaikan tugas kelompok } \\
\text { (masalah diskusi kelompok sama } \\
\text { dengan tugas individu pada fase ke-2 } \\
\text { dan 3) } \\
\text { - Mendorong siswa berbagi informasi } \\
\text { hasil kerja individu } \\
\text { - Membimbing siswa membuat } \\
\text { ringkasan hasil diskusi dan siap } \\
\text { disajikan dalam presentasi kelas. }\end{array}$ & $\begin{array}{l}\text { - Secara berkelompok siswa } \\
\text { berdiskusi menyelesaikan tugas } \\
\text { kelompok. } \\
\text { - } \text { Siswa mendiskusikan dan } \\
\text { menjelaskan alasan mengapa } \\
\text { menggunakan langkah yang } \\
\text { mereka buat. } \\
\text { - } \text { Diharapkan siswa terlatih } \\
\text { nalarnya melalui aktivitas diskusi } \\
\text { dalam kelompok, yaitu dengan } \\
\text { menyampaikan pendapat dan dan } \\
\text { memberikan alasan tentang } \\
\text { pendapat yang disampaikan }\end{array}$ \\
\hline $\begin{array}{l}\text { Fase 5: } \\
\text { Reflection }\end{array}$ & $\begin{array}{l}\text { - Menunjuk salah seorang dari anggota } \\
\text { kelompok mempresentasikan hasil } \\
\text { diskusi kelompok. } \\
\text { - Membimbing siswa membuat } \\
\text { simpulan. }\end{array}$ & $\begin{array}{l}\text { - } \text { Mempresentasikan hasil diskusi } \\
\text { kelompok. } \\
\text { - } \text { Kelompok lain menanggapi atau } \\
\text { bertanya kepada yang presentasi. } \\
\text { - } \text { Membuat simpulan }\end{array}$ \\
\hline
\end{tabular}


Beberapa saran untuk penyempurnaan perangkat pembelajaran adalah (1) beberapa kalimat perlu diperjelas; (2) sebaiknya ditambah uraian konsep; (3) tampilan bilangan pecahan perlu diperbesar. Sedangkan untuk instrumen pengukur kemampuan penalaran siswa secara teoritis dinyatakan valid. Kemampuan penalaran siswa diukur berdasarkan langkah-langkah pemecahan masalah yang dikemukakan oleh Polya (1973) terdiri dari empat tahap, yaitu memahami masalah, membuat rencana penyelesaian, menyelesaikan rencana, dan memeriksa kembali. Peneliti memodifikasi keempat langkah pemecahan masalah tersebut menjadi (1) diketahui, (2) ditanyakan, (3) penyelesaian, dan (4) Cek kembali.

Setelah sintaks model OSCAR, perangkat pembelajaran, instrumen divalidasi dan dinyatakan layak untuk diujicobakan, selanjutnya direvisi sesuai masukan yang diberikan. Langkah selanjutnya dilakukan uji coba di kelas uji coba. Kegiatan uji coba ini dilakukan untuk mengetahui kefektifan model OSCAR serta perangkat pembelajaran yang digunakan. Setelah dilakukan uji coba diperoleh data keterlaksanaan proses pembelajaran (KPP), respon siswa terhadap model pembelajaran OSCAR, dan kemampuan penalaran siswa setelah diterapkannya model pembelajaran OSCAR. Data hasil observasi terhadap KPP disajikan pada Tabel 3.

Tabel 3. Rekapitulasi KPP Model Pembelajaran OSCAR Kelas Uji Coba

\begin{tabular}{lcccc}
\hline $\begin{array}{l}\text { Tahap/ } \\
\text { Sintaks }\end{array}$ & \multicolumn{3}{c}{ Nilai Observer } & Rata \\
\cline { 2 - 4 } Pembelajaran & $\mathbf{1}$ & $\mathbf{2}$ & $\mathbf{3}$ & rata \\
\hline Orientation & 4,00 & 4,00 & 3,70 & 3,90 \\
\hline $\begin{array}{l}\text { Self- } \\
\text { observation }\end{array}$ & 3,25 & 3,50 & 3,30 & 3,35 \\
\hline
\end{tabular}

\begin{tabular}{lcccc}
\hline \multirow{2}{*}{$\begin{array}{l}\text { Tahap/ } \\
\text { Sintaks } \\
\text { Pembelajaran }\end{array}$} & \multicolumn{3}{c}{ Nilai Observer } & Rata \\
\cline { 2 - 4 } & $\mathbf{1}$ & $\mathbf{2}$ & $\mathbf{3}$ & rata \\
\hline Construction & 3,00 & 3,50 & 3,50 & 3,33 \\
\hline Association & 3,25 & 3,25 & 3,50 & 3,33 \\
\hline Reflection & 3,80 & 4,00 & 3,80 & 3,87 \\
\hline Rata-rata & 3,46 & 3,65 & 3,56 & 3,56 \\
\hline
\end{tabular}

Data pada Tabel 3 menunjukkan bahwa rata-rata keterlaksanaan proses pembelajaran sebesar 3,56. Sesuai dengan kriteria yang telah ditentukan, nilai tersebut termasuk kategori sangat baik.

Data lain yang diperoleh dari hasil uji coba adalah respon siswa. Siswa diminta memberi tanggapan terhadap materi pelajaran, Lembar Kerja Siswa (LKS), latihan, dan cara guru mengajar selama pembelajaran menggunakan model pembelajaran OSCAR. Data respon siswa terhadap penerapan model pembelajaran OSCAR disajikan pada Tabel 4.

Tabel 4. Respon Siswa Terhadap Model Pembelajaran OSCAR di Kelas Uji Coba

\begin{tabular}{ccccc}
\hline \multirow{2}{*}{ Uraian } & S & TS & B & TB \\
& $(\%)$ & $(\%)$ & $(\%)$ & $(\%)$ \\
\hline
\end{tabular}

Bagaimana pendapat kalian mengenai:

\begin{tabular}{lcccc}
\hline $\begin{array}{l}\text { 1. Materi } \\
\text { Pelajaran }\end{array}$ & 82 & 18 & 61 & 39 \\
\hline 2. LKS & 30 & 70 & 70 & 30 \\
\hline 3. Latihan & 61 & 39 & 78 & 22 \\
\hline $\begin{array}{l}\text { 4. Cara guru } \\
\text { mengajar }\end{array}$ & 100 & 0 & 100 & 0 \\
\hline $\begin{array}{l}\text { Rata-rata } \\
\text { Rata }\end{array}$ & 32 & 77 & 23
\end{tabular}

Keterangan: $\mathrm{S}=$ senang, TS=Tidak Senang, $\mathrm{B}=\mathrm{B}$ aru, $\mathrm{TB}=$ Tidak Baru 
Rata-rata respon siswa terhadap penerapan model pembelajaran OSCAR dilihat dari empat komponen $68 \%$ siswa menyatakan senang dan $78 \%$ menganggap baru. Hal ini menunjukkan bahwa respon siswa termasuk kategori kuat. Walaupun demikian respon siswa terhadap LKS yang digunakan masih lemah, yaitu hanya $30 \%$ yang senang. Lemahnya respon siswa terhadap LKS sejalan dengan anggapan mereka bahwa LKS yang digunakan masih tergolong baru. Hal ini terlihat dari banyaknya siswa yang menganggap baru sebanyak $70 \%$. Siswa belum terbiasa dengan model LKS yang digunakan. Hal yang paling menonjol adalah cara guru mengajar. Seluruh siswa senang terhadap cara guru mengajar.

Data terakhir yang digunakan untuk mengetahui keefektifan model pembelajaran OSCAR adalah nilai $N$-gain dari kemampuan penalaran siswa. Berdasarkan hasil perhitungan, kemampuan penalaran siswa berdasarkan pretest, posttest, nilai gain dan $N$-gain disajikan pada Tabel 5.

Tabel 5. Kemampuan Penalaran Siswa Berdasarkan Pretest dan Posttes Kelas Uji Coba

\begin{tabular}{lllll}
\hline & $\begin{array}{l}\text { Pre } \\
\text { test }\end{array}$ & $\begin{array}{l}\text { Post } \\
\text { tes }\end{array}$ & Gain & $\begin{array}{l}\boldsymbol{N} \text { - } \\
\text { gain }\end{array}$ \\
\hline Rata-rata & 28,01 & 55,12 & 27,12 & 0,4 \\
\hline $\begin{array}{l}\text { Standard } \\
\text { Deviasi }\end{array}$ & 18,52 & 19,13 & 10,04 & \\
\hline
\end{tabular}

Data pada Tabel 5 menunjukkan bahwa ada peningkatan kemampuan penalaran siswa dalam menyelesaikan masalah matematika setelah mengikuti pembelajaran dengan model OSCAR. Peningkatan tersebut ditunjukkan oleh besarnya nilai $N$-gain sebesar 0,4 . Nilai tersebut termasuk kriteria sedang.

\section{Fase Implementasi}

Fase ini merupakan kegiatan terakhir dari penelitian. Pada fase ini peneliti mengimplementasikan penggunaan model pembelajaran OSCAR ke beberapa sekolah yang setara dengan kelas uji coba. Peneliti melakukan implementasi di empat kelas dari empat sekolah yang berbeda. Hasil analisis data tentang rata-rata kemampuan penalaran siswa dan nilai $N$-gain dari empat kelas yang dijadikan sasaran penelitian disajikan pada Tabel 6.

Tabel 6. Rata-rata Kemampuan Penalaran Siswa dan Nilai $N$-gain Berdasarkan Pretest dan Posttes

\begin{tabular}{lcccc}
\hline & $\begin{array}{c}\text { Kelas } \\
\text { ke-1 }\end{array}$ & $\begin{array}{c}\text { Kelas } \\
\text { ke-2 }\end{array}$ & $\begin{array}{c}\text { Kelas } \\
\text { ke-3 }\end{array}$ & $\begin{array}{c}\text { Kelas } \\
\text { ke-4 }\end{array}$ \\
\hline $\begin{array}{l}\text { Pre } \\
\text { test }\end{array}$ & 0,67 & 30,3 & 14,5 & 10,4 \\
\hline $\begin{array}{l}\text { Post } \\
\text { tes }\end{array}$ & 37,9 & 57,7 & 48,4 & 45,3 \\
\hline $\begin{array}{l}N- \\
\text { gain }\end{array}$ & 0,35 & 0,43 & 0,42 & 0,40 \\
\hline
\end{tabular}

Data pada Tabel 6 menunjukkan bahwa rata-rata kemampuan penalaran siswa mengalami peningkatan. Hal ini terlihat dari besarnya rata-rata nilai $N$-gain dari setiap kelas antara 0,35 sampai 0,43. Peningkatan kemampuan penalaran siswa di semua kelas termasuk kategori sedang.

Peningkatan kemampuan siswa baik pada kelas uji coba maupun kelas implementasi termasuk kategori yang sama, yaitu kategori sedang.

\section{SIMPULAN}

Simpulan dari hasil penelitian ini adalah model pembelajaran OSCAR dengan sintaks Orientation, Self-observation, Construction, dan Reflection telah memenuhi kriteria valid, praktis, layak 
digunakan dan efektif. Hal ini ditunjukkan oleh perolehan nilai rata-rata validitas sebesar 3,32 yang menunjukkan kriteria valid. Aspek kepraktisan ditunjukkan oleh pernyataan para validator bahwa model pembelajaran OSCAR dapat dilaksanakan di lapangan. Aspek efektif ditunjukkan oleh nilai rata-rata keterlaksanaan proses pembelajaran sebesar 3,56 termasuk kategori sangat baik; respon siswa terhadap penerapan model pembelajaran OSCAR $68 \%$ menyatakan senang, $78 \%$ menganggap baru, seluruh siswa senang terhadap cara guru mengajar; rata-rata kemampuan penalaran siswa mengalami peningkatan, hal ini ditunjukkan oleh besarnya rata-rata nilai $\mathrm{N}$-gain antara 0,35-0,43 dan termasuk kategori sedang.

\section{UCAPAN TERIMA KASIH}

Peneliti mengucapkan terima kasih kepada KEMENRISTEKDIKTI yang telah membiayai penelitian. Kepala SD Muhammadiyah 5 Surabaya, Kepala SD Islam Maryam Surabaya, Kepala SD Islam Saroja Surabaya, dan Kepala SD Negeri Sidotopo Wetan I Surabaya yang telah memberi ijin kepada peneliti untuk melakukan penelitian.

\section{DAFTAR PUSTAKA}

Aqib, Z. 2013. Model-model,Media, dan Strategi Pembelajaran Kontekstual (Inovatif). Bandung:YRAMA WIDYA.

Holisin, I, Budayasa, I.K., Suwarsono, St., 2017. "Comparison of Male and Female Primary School Student Reasoning Profiles in Solving Fractional Problems". IJESE: International Journal of Environmental \& Science Education. Vol. 12 (6), pp: 1553-1565

Lidinillah, D.A.M. 2008. Strategi Pembelajaran Pemecahan Masalah di Sekolah Dasar. [Online]

Tersedia:

http://file.upi.edu/Direktori/JURNAL/PENDIDIKAN_DASAR/Nomor_10Oktober_2008/Strategi_Pembelajaran_Pemecahan_Masalah_di_Sekolah_Dasar.pdf. (15 April 2017).

Pape, S. J. 2004. "Middle School Children's Problem-solvingBehavior: a Cognitive Analysis from a Reading Comprehension Perspective". Journal for Research in Mathematics Education. Vol. 35 (3), pp: 187-219.

Plomp, Tj. 1997. Educational Design: Introduction. From Tjeerd Plomp (eds). Educational \& Training System Design: Introduction Design of Education and Training (in Duth). Utrecht (the Netherlands):Lemma. Netherland. Faculty of Educational Science and Technology. University of Twente.

Polya. 1973. How to Solve it. Princetown NJ: Princetown University Press.

Rosiyanti, H. dan Widyasari, N. 2017. "Pengembangan Buku Ajar Bar Modelling Berbasis Pemecahan Masalah pada Tema Berhemat Energi". Fibonacci: Jurnal Pendidikan Matematika. Vol. 3 (2), pp: 111-120.

Shadiq, F. 2004. Pemecahan Masalah, Penalaran, dan Komunikasi. Yogyakarta: Depdiknas, Dirjendikdasmen PPPG Matematika. 
FIBONACCI : Jurnal Pendidikan Matematika dan Matematika

Volume 5 No. 1 Bulan Juni Tahun 2019

Subanji. 2013. Pembelajaran Matematika Kreatif dan Inovatif. Malang:Penerbit Universitas Negeri Malang.

Usman. 2014. “Aktivitas Metakognisi Mahasiswa Calon Guru Matematika dalam Pemecahan Masalah Terbuka". Jurnal Didaktik Matematika. Vol. 1 (2), pp: 21-29.

Wiyono. 2013. "Pembelajaran Matematika Model Concept Attainment Meningkatkan Kemampuan Pemecahan Masalah Materi Segitiga". Journal of Educational Research and Evaluation. Vol. 2 (1), pp: 50-54. 